\title{
Predicted distribution of a rare and understudied forest carnivore: Humboldt martens (Martes caurina humboldtensis)
}

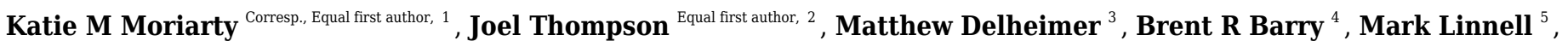 \\ Taal Levi ${ }^{6}$, Keith Hamm ${ }^{7}$, Desiree Early ${ }^{7}$, Holly Gamblin ${ }^{8}$, Micaela Szykman Gunther ${ }^{8}$, Jordan Ellison ${ }^{1}$, Janet \\ Prevéy $^{9}$, Jennifer Hartman ${ }^{10}$, Raymond Davis ${ }^{11}$ \\ ${ }^{1}$ Western Sustainable Forestry, National Council for Air and Stream Improvement, Inc., Corvallis, Oregon, United States \\ 2 Pacific Northwest Region Data Resources Management, USDA Forest Service, Joseph, Oregon, United States \\ 3 Pacific Southwest Research Station, USDA Forest Service, Placerville, California, United States \\ 4 Confederated Tribes of the Grand Ronde, Grand Ronde, Oregon, United States \\ 5 Pacific Northwest Research Station, USDA Forest Service, Corvallis, Oregon, United States \\ 6 Department of Fisheries and Wildlife, Oregon State University, Corvallis, Oregon, United States \\ 7 Green Diamond Resource Company, Korbel, California, United States \\ 8 Department of Wildlife, Humboldt State University, Arcata, California, United States \\ 9 Fort Collins Science Center, US Geological Survey, Fort Collins, Colorado, United States \\ 10 Rogue Detection Teams, Rice, Washington, United States \\ 11 Pacific Northwest Region, USDA Forest Service, Corvallis, Oregon, United States \\ Corresponding Author: Katie M Moriarty \\ Email address: kmoriarty@ncasi.org
}

Background. Many mammalian species have experienced range contractions. Following a reduction in distribution that has resulted in apparently small and disjunct populations, the Humboldt marten (Martes caurina humboldtensis) was recently designated as federally Threatened and state Endangered. This subspecies of Pacific marten occurring in coastal Oregon and northern California, also known as coastal martens, appear unlike martens that occur in snow-associated regions in that vegetation associations appear to differ widely between Humboldt marten populations. We expected current distributions represent realized niches, but estimating factors associated with long-term occurrence was challenging for this rare and little-known species. Here, we assessed the predicted contemporary distribution of Humboldt martens and interpret our findings as hypotheses correlated with the subspecies' niche to inform strategic conservation actions.

Methods. We modeled Humboldt marten distribution using a maximum entropy (Maxent) approach. We spatially-thinned 10,229 marten locations collected from 1996-2020 by applying a minimum distance of 500-m between locations, resulting in 384 locations used to assess correlations of marten occurrence with biotic and abiotic variables. We independently optimized the spatial scale of each variable and focused development of model variables on biotic associations (e.g., hypothesized relationships with forest conditions), given that abiotic factors such as precipitation are largely static and not alterable within a management context.

Results. Humboldt marten locations were positively associated with increased shrub cover (salal (Gautheria shallon)), mast producing trees (e.g., tanoak, Notholithocarpus densiflorus), increased pine (Pinus sp.) proportion of total basal area, annual precipitation at home-range spatial scales, low and high amounts of canopy cover and slope, and cooler August temperatures. Unlike other recent literature, we found litte evidence that Humboldt martens were associated with old-growth structural indices. This case 
study provides an example of how limited information on rare or lesser-known species can lead to differing interpretations, emphasizing the need for study-level replication in ecology. Humboldt marten conservation would benefit from continued survey effort to clarify range extent, population sizes, and fine-scale habitat use. 
1 Predicted distribution of a rare and understudied forest carnivore: Humboldt martens

2 (Martes caurina humboldtensis)

3

4 Katie Moriarty $^{1}$, Joel Thompson ${ }^{2}$, Matthew Delheimer ${ }^{3}$, Brent Barry ${ }^{4}$, Mark Linnell ${ }^{5}$, Taal

5 Levi $^{6}$, Keith Hamm ${ }^{7}$, Desiree Early ${ }^{7}$, Holly Gamblin ${ }^{8}$, Micaela Szykman Gunther ${ }^{8}$, Jordan

6 Ellison ${ }^{1}$, Janet S. Prevéy ${ }^{9}$, Jennifer Hartman ${ }^{10}$, Ray Davis ${ }^{11}$

81 Western Sustainable Forestry, National Council for Air and Stream Improvement, Inc.,

9 Corvallis, Oregon, USA

102 Pacific Northwest Region Data Resources Management, USDA Forest Service,

11 Joseph, Oregon, USA

$12{ }^{3}$ Pacific Southwest Research Station, USDA Forest Service, Placerville, California,

13 USA

$14{ }^{4}$ Confederated Tribes of the Grand Ronde, Grand Ronde, Oregon, USA

$15{ }^{5}$ Pacific Northwest Research Station, USDA Forest Service, Corvallis, Oregon, USA

$16{ }^{6}$ Department or Fisheries and Wildlife, Oregon State University, Corvallis, Oregon, USA

177 Green Diamond Resource Company, Korbel, California, USA

$18{ }^{8}$ Department of Wildlife, Humboldt State University, Arcata, California, USA

199 USGS Fort Collins Science Center, 2050 Centre Ave Building C, Fort Collins, CO

20 80526, USA

2110 Rogue Detection Teams, Rice, Washington, USA

$22{ }^{11}$ Pacific Northwest Region, USDA Forest Service, Corvallis, Oregon, USA

24 Corresponding Author: 
25 Katie Moriarty $^{1}$

26 NCASI, Inc., 227 NW Third Street, Corvallis, OR, 97330, USA

27 Email address: kmoriarty@ncasi.org

28 


\section{Abstract}

30 Background. Many mammalian species have experienced range contractions. Following a

31 reduction in distribution that has resulted in apparently small and disjunct populations, the

32 Humboldt marten (Martes caurina humboldtensis) was recently designated as federally

33 Threatened and state Endangered. This subspecies of Pacific marten occurring in coastal

34 Oregon and northern California, also known as coastal martens, appear unlike martens that occur in snow-associated regions in that vegetation associations appear to differ widely between Humboldt marten populations. We expected current distributions represent realized niches, but estimating factors associated with long-term occurrence was challenging for this rare and little-known species. Here, we assessed the predicted contemporary distribution of Humboldt martens and interpret our findings as hypotheses correlated with the subspecies' niche to inform strategic conservation actions.

Methods. We modeled Humboldt marten distribution using a maximum entropy (Maxent) approach. We spatially-thinned 10,229 marten locations collected from 1996-2020 by applying a minimum distance of $500-\mathrm{m}$ between locations, resulting in 384 locations used to assess correlations of marten occurrence with biotic and abiotic variables. We independently optimized the spatial scale of each variable and focused development of model variables on biotic associations (e.g., hypothesized relationships with forest conditions), given that abiotic factors such as precipitation are largely static and not alterable within a management context.

Results. Humboldt marten locations were positively associated with increased shrub cover (salal (Gautheria shallon)), mast producing trees (e.g., tanoak, Notholithocarpus densiflorus), increased pine (Pinus sp.) proportion of total basal area, annual precipitation at home-range spatial scales, low and high amounts of canopy cover and slope, and cooler August temperatures. Unlike other recent literature, we found little evidence that Humboldt martens were associated with old-growth structural indices. This case study provides an example of how limited information on rare or lesser-known species can lead to differing interpretations, 
55 emphasizing the need for study-level replication in ecology. Humboldt marten conservation

56 would benefit from continued survey effort to clarify range extent, population sizes, and fine-

57 scale habitat use.

58

59 Key words: California, distribution model, habitat relationships, Humboldt marten, Martes caurina humboltensis, Maxent, rare species, Oregon, Pacific marten

61

62

63

64

\section{Introduction}

Modeling predicted distributions is important to direct conservation efforts yet creating accurate predictions is challenging for rare, declining, or understudied species (Raphael \& Molina, 2007). For instance, constriction of the range available to a species - it's realized niche - is the actualization of used conditions, but such conditions may change (Colwell \& Rangel, 2009). Contemporary location information may further associate a species with conditions that were unaffected by prior agents of population decline, but not with favored characteristics where the species resided prior (Caughley, 1994). For instance, bison (Bison bison) were historically widely distributed throughout the Great Plains of North America (Shaw, 1995), yet a contemporary species distribution model would associate bison occurrence with conditions where the few relict populations reside, including the extremely cold winters and thermal geysers of Yellowstone National Park. Appropriate interpretation of the conditions that constitute suitable habitat is requisite for species' management and spatial models may help predict occurrence (Sofaer et al., 2019).

Humboldt martens (Martes caurina humboldtensis) are a distinct subspecies of the Pacific marten (M. caurina) that historically occurred throughout coastal forests of 
79 northern California and Oregon (Schwartz et al., 2020). Humboldt martens were thought

80 to be increasingly rare almost a century ago (Grinnell \& Dixon, 1926) and were

81 considered to be extirpated in California and extremely rare in Oregon for the latter half

82 of the $20^{\text {th }}$ century (Zielinski et al., 2001). In 1996, the Humboldt marten was

83 rediscovered in California (Zielinski \& Golightly, 1996). Subsequent research efforts

84 over the last two decades have elucidated some aspects of Humboldt marten ecology

85 and demography (e.g., Linnell et al., 2018; Delheimer et al., In press), including surveys

86 to evaluate Humboldt marten distribution (e.g., Gamblin, 2019; Moriarty et al., 2019).

87 Such investigations have improved our knowledge of where Humboldt martens occur

88 yet the full geographic extent of the contemporary distribution remains unknown,

89 although it appears to compose a fraction of the historical distribution (USFWS, 2020).

90 This putative range contraction has resulted in apparently small and disjunct

91 populations (USFWS, 2019), which has engendered substantial concern for the species'

92 persistence. Consequently, Humboldt martens were listed as Endangered under the

93 state of California's Endangered Species Act (CDFW, 2019) and as Threatened under

94 the federal Endangered Species Act as a "coastal distinct population segment" of

95 Pacific martens (USFWS, 2020).

96 Clarifying the contemporary Humboldt marten distribution by identifying areas

97 where martens may occur that have not been surveyed and predicting the future

98 distribution (e.g., identifying areas where martens may not currently occur but could

99 colonize) is urgently needed for conservation planning. Nonetheless, modeling the

100 distribution of Humboldt martens is constrained by apparent non-stationary associations

101 between extant populations, and vegetation associations that contradict the prevailing 
102 paradigm for North American martens. For instance, it has generally been recognized

103 that North American martens occur in mature forests characterized by dense canopy

104 cover, presence of large diameter and decadent trees and snags, and abundant coarse

105 woody debris (Thompson et al., 2012). Although initial investigations primarily

106 associated Humboldt martens with similar conditions (Slauson, Zielinski \& Hayes,

107 2007), subsequent studies have indicated that Humboldt martens also occur in young

108 forests ( $<80$ years old) with modest canopy cover and relatively small diameter trees

109 (Eriksson et al., 2019; Moriarty et al., 2019). Dense and spatially-extensive shrubs, also

110 an uncharacteristic vegetation association for martens elsewhere in North America, was

111 a consistent habitat component in most studies of Humboldt martens (Slauson, Zielinski

112 \& Hayes, 2007; Eriksson et al., 2019; Gamblin, 2019; Moriarty et al., 2019). Similarly,

113 European pine martens (Martes martes) have long been considered a habitat specialist

114 associated with older forests (Storch, Lindstrom \& de Jounge, 1990; Brainerd \& Rolstad,

115 2002), yet have recently been documented in a wide variety of habitat types including

116 shrublands, grasslands, and agricultural areas (Lombardini et al., 2015; Balestrieri et al.,

117 2016; Moll et al., 2016; Manzo et al., 2018).

118 Observations that are limited in space or time may not identify the conditions

119 necessary for population persistence, which could result in a misrepresentation of a

120 species' niche. A previous range-wide Humboldt marten distribution model by Slauson

121 et al. (2019) emphasized a strong correlation between Humboldt marten occurrence

122 and an "old-growth structural index" (OGSI) variable, which is a composite index of

123 factors considered common to old-growth forests in the region, including density of large

124 live trees, snags, and downed wood, stand age, and diversity of tree sizes (Davis et al., 
125 2015). However, more recent and broader-scale research efforts suggest that

126 associations between OGSI and Humboldt marten distribution are much less clear (e.g.,

127 Barry 2018; Gamblin 2019; Linnell et al. 2018; Moriarty et al. 2019). A potential

128 mismatch in previously-predicted associations between vegetation and Humboldt

129 marten distribution could lead to a "wicked problem" by focusing management or

130 restoration in areas that may not benefit the species across its range (Gutiérrez, 2020).

131 Here, our objective was to create a contemporary range-wide model of predicted

132 Humboldt marten distribution that includes recent location data collected from broad-

133 scale randomized surveys throughout the historic range, combined with more recent

134 and accurate vegetation layers (e.g., shrub layers). Our goal was to predict factors

135 contributing to Humboldt marten distribution and to highlight areas for future surveys

136 and conservation efforts.

138 Materials \& Methods

139 Study Area

140 We collected data throughout coastal northern California and Oregon. The

141 Humboldt marten is considered to occur in four Extant Population Areas (EPAs), which

142 were created using minimum convex polygons around clusters of marten detections, but

143 excluded clusters with smaller numbers of detections $(<5)$ or detections $>5 \mathrm{~km}$ from

144 other detections (USFWS 2019). As such, our surveys included both the recognized

145 EPAs (Central Coastal Oregon, Southern Coastal Oregon, California-Oregon Border,

146 and Northern Coastal California; Figure 1) but also extended between these designated

147 boundaries to include the historic range (USFWS 2019). 
Surveys in California occurred in both near-coastal and montane areas (Klamath

149 Mountains, California Coast Range) that received substantial precipitation (100-300 cm

150 annual precipitation) with cooler $\left(7-10^{\circ} \mathrm{C}\right)$ temperatures and drier summers dominated

151 with fog and low cloud moisture (Rastogi et al., 2016). Forest types included a mix of

152 coniferous and hardwood with a spatially-extensive shrub understory and dominant tree

153 species included redwood (Sequoia sempervirens) along the coast and Douglas-fir

154 (Pseudotsuga menziesii) in the mountains (Whittaker, 1960).

155 Surveys in Oregon similarly occurred in both near-coastal and montane areas

156 (Oregon Coast Range) where dominant forest types included Sitka spruce (Picea

157 sitchensis) and shore pine (Pinus contorta) along the coast and western hemlock

158 (Tsuga heterophylla) slightly inland (Franklin \& Dyrness, 1973). The Sitka spruce zone was characterized by a wet and moderately warm maritime climate with average annual

160 temperatures of $10-11^{\circ} \mathrm{C}$, average annual precipitation of $200-300 \mathrm{~cm}$, and frequent fog

161 and cloud cover. The western hemlock zone, which was often co-dominated by

162 Douglas-fir, was somewhat cooler $\left(7-10^{\circ} \mathrm{C}\right.$ average annual temperature) and drier (150-

$163300 \mathrm{~cm}$ annual precipitation) with fairly extensive summer fog and low cloud cover (Dye 164 et al., 2020).

165 Common conifer species intermixed and included western hemlock, Port Orford 166 cedar (Chamaecyparis lawsoniana), and western redcedar (Thuja plicata). Hardwood

167 trees included tanoak (Notholithocarpus densiflora), giant chinquapin (Castanopsis

168 chrysophylla), coastal live oak (Quercus agrifolia), canyon live oak (Q. chrysolepis),

169 California bay (Umbellularia californica), red alder (Alnus rubra), bigleaf maple (Acer

170 macrophyllum), and Pacific madrone (Arbutus menziesii). Dominant shrubs throughout 
171 the study area included salal (Gautheria shallon), evergreen huckleberry (Vaccinium

172 ovatum), Pacific rhododendron (Rhododendron macrophyllum), and red huckleberry (V.

173 parvifolium).

174

175 Marten locations

176 We used spatially-referenced Humboldt marten locations collected between 1996 and

1772020 in California and Oregon. We excluded locations occurring in areas that were

178 modified by fire or timber harvest after the location date and prior to 2016 , the date

179 represented by our vegetation data. If multiple locations occurred within a 500-m x 500-

$180 \mathrm{~m}$ grid cell, we spatially-thinned locations to randomly include one in each cell,

181 attempting to achieve spatial independence for modeling (Kramer-Schadt et al., 2013).

182 Priority for location retention from highest to lowest was: (1) rest and den locations from

183 telemetry (Linnell et al., 2018; Delheimer et al., In press); (2) locations from scat dog

184 detection surveys (Moriarty et al., 2018; Moriarty et al., 2019); and (3) locations from

185 baited camera and/or track plate surveys (Slauson, Baldwin \& Zielinski, 2012; Barry,

186 2018; Gamblin, 2019; Moriarty et al., 2019). We used presence-only data because

187 surveys that occurred prior to 2014 were often missing detection histories from non-

188 detection (e.g., absence) locations.

189 For the data for which the authors were responsible, our protocols were reviewed

190 and approved by the USDA Forest Service Research and Development Institutional

191 Care and Use Committee (permits 2015-002, 2017-005) or Humboldt State University

192 Institutional Care and Use Committee (permit 16/17.W.05-A). We obtained Scientific

193 Take Permits for hair snares and samples collected through the Oregon Department of 
194 Fish and Wildlife (ODFW 119-15, 128-16, 033-16, 109-19, 107-20). Older verified

195 survey data were provided by the US Fish and Wildlife Service with no additional

196 information.

197

198 Modeling approach

199 Our modeling approach included Humboldt marten locations, biotic and abiotic predictor

200 variables, and randomly generated pseudo-absence points. We used a minimum

201 convex polygon (MCP) around Humboldt marten locations buffered by $10 \mathrm{~km}$ to define

202 the modeling region (Fig. 1b). We chose a $10 \mathrm{~km}$ buffer because it approximated the

203 upper quartile of daily marten movement (Moriarty et al., 2017). We projected our model

204 to available vegetation data from Gradient Nearest Neighbor (GNN) data supplied by

205 the Landscape Ecology, Modeling, Mapping and Analysis lab (Bell, Gregory \& Davis,

206 2020; Bell et al., 2021), which included the coastal and Klamath level-3 eco-provinces

207 (U.S. Environmental Protection Agency, 2013). We removed urban areas and water

208 from the background data (Davis et al., 2016). We summarized the range, average, and

209 standard deviation for each variable within the modeling region and study area (Table 1,

210 Fig. 1).

211

\section{Biotic variables}

213 Biotic variables in our models included forest structure and composition, forest age,

214 canopy cover, OGSI, percent pine, percent mast, and predicted shrub cover, as

215 described below. 
We used the 2016 version of GNN (Ohmann \& Gregory, 2002) to incorporate

217 forest structure variables including forest age, canopy percent cover, OGSI, and percent

218 pine. Forest age was the basal area-weighted age based on field-recorded or modeled

219 ages of dominant and codominant trees. Canopy percent cover was calculated using

220 the Forest Vegetation Simulator (Crookston \& Stage, 1999). Our OGSI index ranged

221 from 0-100 was based from 4 elements: density of large diameter live trees per hectare,

222 density of large diameter snags per hectare, percentage of downed wood greater than

$22325 \mathrm{~cm}$ in diameter, and an index of tree diameter diversity computed from tree densities

224 in different diameter classes (Davis et al., 2015). For live trees and snags, "large

225 diameter" was dependent on forest type and was defined for twelve vegetative zones,

226 each zone with a unique minimum diameter threshold (i.e., ranging 50-100 cm for live

227 trees, $50-75 \mathrm{~cm}$ for snags (Davis et al. (2015); see Supplemental information (Item S1)

228 for more information on integration of the OGSI variable into our model).

229 We created a variable called "percent pine", which was the combined percentage

230 of total basal area of shore pine, Jeffery pine $(P$. jefferii), and knobcone pine $(P$.

231 attenuata) from GNN. This variable was included because martens have been detected

232 in shore pine communities in the Oregon Central Coast population (Linnell et al., 2018;

233 Eriksson et al., 2019), and in areas with serpentine soils characterized by sparse cover

234 of Jeffery and knobcone pine, stunted tree growth, and dense shrub understories

235 (Kruckeberg, 1986; Safford, Viers \& Harrison, 2005; Harrison et al., 2006; Slauson et

236 al., 2019). We visually inspected the congruence of the serpentine soil layer created by

237 the US Fish and Wildlife Service (Schrott \& Shinn, 2020) with our percent pine layer, 238 confirming overlap between the two variables. 
Humboldt martens have been associated with dense shrub cover throughout

240 their range (Slauson, Zielinski \& Hayes, 2007; Moriarty et al., 2019). Salal and

241 evergreen huckleberry appear particularly important, as the berries of each occur in

242 Humboldt marten diets and provide food for marten prey species (Eriksson et al., 2019;

243 Manlick et al., 2019; Moriarty et al., 2019). We modeled probabilities of species

244 occurrence of salal and evergreen huckleberry, creating the model for evergreen

245 huckleberry following methods published for salal and other shrub species (Prevéy,

246 Parker \& Harrington, 2020; Prevéy et al., 2020). We related locations to contemporary

247 (1981-2010) bioclimatic variables from the AdaptWest project (Wang et al., 2016) to

248 depict the probability of species occurrence (1-100\%). Humboldt marten diet is

249 dominated by animals (e.g., passerines, ground squirrels) that feed on berries and mast

250 and Humboldt martens also directly consume berries (Slauson \& Zielinski, 2017;

251 Eriksson et al., 2019; Manlick et al., 2019). The "mast" variable represented hardwood

252 tree and shrub species that produce nuts, seeds, buds, or fruits eaten by wildlife and

253 was estimated using the 2016 GNN layer as the percent of total basal area comprised

254 of tanoak, giant chinquapin, coastal live oak, canyon live oak, and California bay.

256 Abiotic variables

257 Abiotic variables included temperature $\left({ }^{\circ} \mathrm{C}\right)$, precipitation $(\mathrm{cm})$, cloud cover $(\%)$, coastal

258 proximity, percent slope, and topographic position index. We used 30-year normal

259 PRISM variables of Average Annual Precipitation converted to $\mathrm{cm}$ and Maximum

260 Temperature in August at an 800-m scale (1981-2010, PRISM Climate Group, Oregon

261 State University, http://prism.oregonstate.edu, created 10/17/2019) as a proxy for 
262 maximum annual temperature. We explored annual data for temperature (2010-2018),

263 but the available $4 \mathrm{~km}$ resolution produced artifacts in the model.

264 We created models with the variable Coastal Proximity, which uses PRISM data

265 and combines coastal proximity and temperature advection influenced by terrain (Daly,

266 Helmer \& Quiñones, 2003) modified for the western United States (Daly et al., 2008).

267 We derived percent slope and topographic position index from US Geological Survey

268 digital elevation models. Topographic position index is an indicator of slope position and

269 landform category; it is the difference between the elevation at a single cell and the

270 average elevation of the user-defined radius around that cell (Jenness, 2006).

272 Scale optimization

273 Given that martens select habitat at multiple scales (e.g., broad-scale landscape

274 features) and fine-scale features within home ranges (4th order selection; e.g., Minta,

275 Kareiva \& Curlee, 1999), we optimized the spatial scale of each variable included in the

276 model. We smoothed variables using the extract function in package raster in $\mathrm{R}$

277 (Hijmans, 2020; R Core Team, 2020) with a radius of $50 \mathrm{~m}, 270 \mathrm{~m}, 742 \mathrm{~m}$, and $1170 \mathrm{~m}$.

278 Our smallest scale ( $50 \mathrm{~m}, 0.81 \mathrm{ha}$ ) provided local and fine-scale conditions. We

279 assumed $270 \mathrm{~m}$ (20 ha) approximated the size of a Humboldt marten core area, similar

280 to optimized scales of vegetation characteristics used in predicting conditions for marten

281 rest structures elsewhere in California (Tweedy et al., 2019). The scale of $742 \mathrm{~m}$ (174

282 ha) represented an approximate female Humboldt marten home range size, calculated

283 as the average of female home range estimates (173 ha) from two previous studies

284 (Linnell et al., 2018; Supplemental Data S1; PSW, 2019).Our broadest scale was based 
285 on the largest size of a Humboldt marten male home range (1170 m, 428 ha,

286 Supplemental Data S1), assuming a male would overlap multiple females and could be

287 interpreted as the smallest unit of population level selection (Linnell et al., 2018; PSW,

288 2019). We used individual univariate linear models ( $\mathrm{glm}$ ) for each spatial scale using our

289 training location data and a random background sample of 9,600 points (25 times the

290 location data) within the MCP at different locations than the Maxent generated pseudo-

291 absence data (Supplemental Data S2). Similar to prior examples (Wasserman et al.,

292 2010; McGarigal et al., 2016; Zeller et al., 2017), we selected the scale for each variable

293 that had the most extreme, and thus the most predictive, coefficient as well as the

294 lowest Akaike's Information Criterion (AIC) value. We also visually inspected the fit of

295 each spatial scale using boxplots (Supplemental Figs. S1, S2, S3).

296 We provided boxplots to visually estimate whether our final variables were similar

297 between all marten locations, thinned marten locations, available surveyed locations

298 without detections (non-detection), and random locations (Fig. 2).

299

300 Predicted distribution

301 We used Maxent modeling software v3.4.1 (Phillips, Anderson \& Schapire, 2006) to

302 estimate the relative probability of Humboldt marten presence (Merow, Smith \&

303 Silander, 2013). Maxent uses a machine learning process to develop algorithms that

304 relate environmental conditions at documented species' presence locations to that of

305 the surrounding background environment in which they occurred (Phillips \& Dudík,

306 2008; Elith et al., 2011). We excluded variables with highly correlated predictors

307 (|Pearson coefficient| > 0.6), selecting the variable that was most interpretable for 
308 managers (Table S2). During this process, we considered the variance inflation (Table

309 S3), which allows for evaluation of correlation and multicollinearity. Variance inflation

310 factors equal to 1 are not correlated and factors greater than 5 are highly correlated as

311 determined by $\left(1 /\left(1-R_{i}^{2}\right)\right)$, where $R_{i}^{2}$ is squared multiple correlation of the variable $i$

312 (Velleman \& Welsch, 1981).

313 Within each model iteration, we selected the bootstrap option with 10 replicates,

314 random seed, and 500 iterations. We trained our models using a random subset of $75 \%$

315 of presence locations and tested these using the remaining $25 \%$ with logistic output. We

316 used the default of 10,000 pseudo-absence background samples. We varied the

317 response functions to include linear, product, and quadratic features. We selected the

318 "auto features" option for all runs, which allows Maxent to further limit the subset of

319 response features from those selected by retaining only those with some effect.

320 Species distribution maps were produced from all models using the maximum

321 training sensitivity plus specificity threshold, which minimizes both false negatives and

322 false positives. We evaluated the AUC statistic to determine model accuracy and fit to

323 the testing data (Fielding \& Bell, 1997). The AUC statistic is a measure of the model's

324 predictive accuracy, producing an index value from 0.5 to 1 , with values close to 0.5

325 indicating poor discrimination and a value of 1 indicating perfect predictions (Elith et al.,

326 2006). We assessed variables using response curves, variable contributions, and

327 jackknife tests. We used percent contribution and permutation importance to determine

328 importance of input variables in the final model (e.g., Halvorsen (2013). Percent

329 contribution can be more informative with uncorrelated variables (Halvorsen 2013), 
330 while permutation importance provides better variable assessment when models and

331 variables are correlated (Searcy \& Shaffer (2016).

332 Because over-parameterized models tend to underestimate habitat availability

333 when transferred to a new geography or time period, we used selection methods

334 suggested by Warren \& Seifert (2011). Maxent provides the option of reducing

335 overfitting with a regularization multiplier that can be altered by the user to apply a

336 penalty for each term included in the model ( $\beta$ regularization parameter) to prevent

337 overcomplexity or overfitting (Merow, Smith \& Silander, 2013; Morales, Fernández \&

338 Baca-González, 2017). A higher regularization multiplier will reduce the number of

339 covariates in the model, becoming more lenient with an increased sample size (Merow,

340 Smith \& Silander, 2013). We did not include model replicates, an option in the interface,

341 to output the required data (lambda file) and set output to logistic. We altered the

342 Regularization Multiplier from 0.5 to 4 for each 0.5 increment (e.g., Radosavljevic \&

343 Anderson (2014).

344 We ranked candidate models using AIC corrected for small sample sizes $\left(\mathrm{AIC}_{\mathrm{c}}\right.$;

345 Burnham \& Anderson 2002). We considered the model with the lowest $\mathrm{AIC}_{\mathrm{c}}$ value to be

346 our top model with those with $\Delta \mathrm{AIC}_{\mathrm{c}}<2$ to be competitive models. For our top model, we

347 generated predicted-to-expected $(\mathrm{P} / \mathrm{E})$ ratio curves for our model using only the testing

348 data to evaluate its predictive performance, which was based on the shape of the

349 curves, a continuous Boyce index (Boyce et al., 2002), and Spearman rank statistics.

350 We used the predicted-to-expected curve to inform our suitability thresholds following

351 Hirzel et al. (2006). We defined unsuitable in areas where the model performed equal to

352 or poorer than random chance (P/E $\leq 1)$ with the lower $95 \%$ confidence interval of the 
353 P/E curve overlapping 0 . For predicted suitable and highly suitable locations, we divided

$354 \mathrm{P} / \mathrm{E}$ and their respective $95 \%$ confidence values greater than 1, categorizing the lower

355 half of data as suitable and the upper portion as predicted highly suitable.

357 Results

358 Locations

359 We compiled 10,229 Humboldt marten locations collected during 1996-2020 (542 baited

360 station, 263 detection dog team, 831 VHF telemetry, 8,537 GPS telemetry, 15 roadkill,

361 and 41 others). Our GPS data represented locations taken every 2.5-5 minutes on 7

362 individuals within the Central Coast (Linnell et al., 2018), and we did not display those

363 clustered data. After we spatially-thinned locations, 384 locations remained and were

364 spread among Extant Population Areas: Central Coastal Oregon ( $n=77$ locations),

365 Southern Coastal Oregon ( $n=77$ locations), California-Oregon Border $(n=33$

366 locations), and Northern Coastal California ( $n=192$ locations) (Fig. 1). There were 5

367 locations that did not occur within boundaries of any EPA (USFWS 2019). Location

368 types included den or rest structure locations (18\%), genetically verified scats or

369 telemetry locations (32\%), and baited camera or track plate locations $(50 \%)$.

370 Thinned locations had similar medians and data distributions to the full location

371 dataset, except for mast and precipitation where the medians were slightly lower for the

372 thinned locations (Fig. 2). Non-detection locations had similar medians and data

373 distributions to random locations, with the most notable difference between medians for

374 salal (Table 1, Fig. 2). Differences between non-detection and random locations were

375 likely due to clustered sampling efforts (Fig. 1b). 


\section{Distribution modeling}

378 Our final model included 8 variables after excluding correlated variables (Table S2,

379 Table S3). Variables in our model were optimized at the home range spatial scale

$380(1,170 \mathrm{~m})$ except OGSI $(50 \mathrm{~m})$, but differences between scales were modest (Figs. S1-

381 S3). Our top model had a Regularization Multiplier of 1.5. Predictor variables, in order of

382 percent contribution, included a positive relationship with salal (23.3\%), percent pine

383 (22.5\%), average annual precipitation (21.6\%), canopy cover (18.7\%), and mast (5.4\%)

384 followed by a negative relationship with average maximum August temperature (4.7\%),

385 percent slope (2.7\%), and OGSI (1.1\%, Table 2). Permutation importance was similar

386 with the same top four variables highly contributing, but with a slightly modified order of

387 percent pine (30.3\%), average annual precipitation $(25.3 \%)$, canopy cover $(20.2 \%)$, and

388 salal (15.5\%; Table 2). The OGSI variable contributed least for both metrics.

We interpreted Maxent's univariate response curves and provide the marginal

390 plots as a supplemental figure (Fig. S4). Marten locations were correlated with both low

391 and high amounts of canopy cover and percent slope (quadratic response, Fig. 3).

392 Moderate amounts of canopy cover (e.g., 5-50\%) appeared to be negatively correlated

393 with marten locations. Predicted marten distribution was positively correlated with salal

394 with some likelihood of a threshold at high values (Fig. 3), percent pine (Fig. 3), average

395 annual precipitation (Fig. 3), and mast (Fig. 3). There was a negative correlation

396 between marten locations and August temperature (Fig. 3) and a slightly negative to

397 neutral relationship between marten locations and OGSI (Fig. 3). 
The predicted versus expected curve of our final model delineated unsuitable

399 areas as $<14 \%$, suitable areas as $15-30 \%$, and predicted highly suitable at $>30 \%$

400 predicted probability (Fig. 4, Data S3) with an AUC value on the test data at 92\%. The

401 model depicted southern Oregon and northern California as having the largest spatial

402 extent for predicted marten distribution, including areas south of the current known

403 distribution (Fig. 5, Data S3).

\section{Discussion}

406 We developed a range-wide species distribution model for the Humboldt marten based

on extensive survey effort and incorporation of contemporary vegetation and climatic

conditions. Our model is complementary, but not similar, to other Humboldt marten

409

distribution models (e.g., Slauson et al. 2019), which could lead to confusion when

410 attempting to understand Humboldt habitat associations. Instead of interpreting

411 differences between models as a conflict, we posit this as evidence of the conservation

412 challenge described by Caughley (1994) and representative of the difficulty in

413 establishing patterns of causality from observational studies. Nonetheless, our model

414 predicted areas where Humboldt martens are known to occur and identified areas of

415 potential occurrence outside of known population extents, which can be placed within

416 an ecological theory framework for managers. As with all models, there are limitations

417 associated with our predictions, and a clear assessment of these constraints is critical

418 for model results to be accurately used to inform management decisions (Sofaer et al.,

419 2019). 
The role of biotic interactions in shaping the distribution of species has been

421 reported (e.g., Forchhammer et al., 2005; Guisan \& Thuiller, 2005), yet evidence of the

422 importance of biotic variables alongside abiotic variables for predicting distributions at

423 larger spatial scales has been largely lacking (e.g., Wisz et al., 2013). High amounts of

424 shrub cover appears to be the most prevalent component of Humboldt marten locations

425 in both California (Slauson \& Zielinski 2009, Slauson et al. 2007) and Oregon (Moriarty

426 et al., 2019) and accordingly, both salal and mast (including mast-producing shrubs)

427 had a strong contribution to our model. Although associations with shrub cover or mast

428 are generally uncharacteristic of martens, European pine martens may occur in areas of

429 dense shrubs (Lombardini et al., 2015) and American marten population numbers in

430 New York appear correlated with mast in hardwood forests (Jensen et al., 2012). Our

431 finding that Humboldt marten distribution was strongly correlated with canopy cover is

432 consistent with previous marten research (Bissonette et al. 1997, Hargis et al. 1999),

433 although our response was quadratic, suggesting marten locations were associated with

434 both low and high levels of canopy cover. Marten populations are typically associated

435 only with relatively dense and increasing canopy cover (Shirk, Raphael \& Cushman,

4362014 ) and we posit that a quadratic response to canopy cover by Humboldt martens

437 may be a function of shrub cover. Although additional information is needed to describe

438 fine-scale vegetation associations, forest conditions with a dense understory layer of

439 shrub and mast-producing species represent achievable targets that can guide

440 management or restoration.

441 Biotic variables influencing predicted Humboldt marten distribution in our model

442 were consistent with previous literature with some exceptions, most notably forest age 
443 and OGSI. Within our model, the predicted relationship between Humboldt marten

444 distribution and higher OGSI values was not only weak but often negative

445 (Supplemental Item S1). The OGSI variable may, in fact, represent an interpretive

446 mismatch with shrub cover - some areas where Humboldt martens occur (e.g., mature

447 Douglas fir forest; Slauson et al. 2007) are characterized by both older forest conditions

448 (i.e., high OGSI values) and substantial shrub cover, while other areas (e.g., serpentine

449 or coastal pine forests; Eriksson et al. 2019, Moriarty et al. 2019) are characterized by

450 substantial shrub cover, but not older forest conditions (i.e., low OGSI values). As an

451 example of this mismatch, much of the putative distribution of Humboldt martens in

452 coastal Oregon and California is dominated by mature western hemlock forests with

453 high OGSI values, yet Humboldt martens are not strongly associated with such areas

454 (Moriarty et al. 2019), possibly because hemlocks are a shade-tolerant species that

455 prohibit understory growth such as shrubs (Kerns \& Ohmann, 2004). When examining

456 our marten locations in a model only with the components of OGSI, downed wood was

457 the most influential variable (Supplemental Item S1). We suspect the differences

458 between our model and the Slauson et al. (2019) model resulted from non-stationary

459 vegetation associations that were only revealed by increased survey effort across a

460 broader geographic scope. While the Slauson et al. (2019) model relied on a modest

461 number of Humboldt marten detections from 1996-2010 with poor coverage outside of

462 northern California (USFWS 2019), our model included a relatively large number of

463 detections that occurred across a longer period of time (1996-2020), over a broader

464 geographic scope in both California and Oregon (Barry 2018; Gamblin 2019; Linnell et

465 al. 2018; Moriarty et al. 2019). 
Range limit theorems have long postulated the importance of elevation, altitude,

467 and weather in determining the limits of species distributions (e.g., Darwin, 1859).

468 Precipitation was one of the top 3 predictive variables in all model simulations and

469 abiotic factors such as increased precipitation, proximity to the coast, and cool

470 temperatures likely influence vegetation type and composition. If these variables are

471 causally linked to marten occurrence, a plausible mechanism is that cooler wetter

472 conditions result in dense vegetation growth (e.g., shrubs). In areas with relatively low

473 canopy cover but dense shrubs, shrub cover may be functionally similar to canopy

474 cover by offering increased protection from predators (Hawley \& Newby, 1957). High

475 shrub cover also likely results in an increased availability of berries and mast. Given that

476 martens consume prey items (e.g., birds, rodents) that feed on berries and mast, while

477 also consuming berries themselves, shrubs may both indirectly and directly subsidize

478 marten diets. If increased shrub cover decreases predation risk while simultaneously

479 providing abundant food resources, such areas may provide exceptional, if

480 uncharacteristic, marten habitat (Eriksson et al., 2019). If this is a potential mechanism,

481 an example includes the abundance of huckleberries that have been attributed to

482 increased reproduction and population growth for grizzly bears (Ursus arctos) over a 32-

483 year investigation (McLellan, 2015).

Species' distributions may also be strongly influenced by less-apparent factors

such as interspecific interactions with predators or competitors (Siren, 2020). As an

example, spotted owls (Strix occidentalis) closely align with old-growth forest conditions

which have been characterized with relatively high accuracy (Davis et al., 2016), yet

spotted owl population viability is dramatically decreased with presence of barred owls 
489 (S. varia) due to interspecific competition and predation (Wiens, Anthony \& Forsman,

490 2014; Diller et al., 2016; Dugger et al., 2016). Although few examples exist for

491 carnivores, a recent evaluation suggests that while lynx (Lynx lynx) distributions are

492 closely-tied to deep snow, the influence of reducing bobcat (L. rufus) competition was

493 stronger than the influence of snow itself (Siren, 2020). A directed research effort that

494 integrates the influence of vegetative and climatic associations with other factors such

495 as prey availability, predation pressure, and competition would provide better insight on

496 the drivers of Humboldt marten occurrence and a more holistic determination of marten

497 distribution.

498 Our results predict some of the components that comprise suitable marten

499 habitat but describing optimal habitat would be best informed by measures of survival

500 and fecundity. Future endeavors could develop site-specific models, ideally using

501 telemetry data that are biologically linked with fitness (e.g., long-lived adult female rest

502 and den structures) to address predicted habitat. We lack enough information regarding

503 where Humboldt martens resided historically to compare with our contemporary

504 distribution (Loehle, 2020), and we are generally ignorant of population densities, causal

505 associations of population declines, and population limitations. Such an understanding

506 is essential to describe expectations of future range (Brown, Stevens \& Kaufman,

507 1996). Finally, the lack of consistency among Humboldt marten studies is suggestive of

508 imperfect knowledge of what components constitute Humboldt marten habitat. To avoid

509 differing views for rare species conservation (e.g., Gutiérrez, 2020; Jones et al., 2020),

510 amassing information collaboratively with a goal of prospective meta-analyses and 
511 study-level replication will be essential (Facka \& Moriarty, 2017; Nichols, Kendall \&

512 Boomer, 2019).

513

514 Conclusions

515 Based on our modeling and an evaluation of available evidence, we conclude that the

516 most consistent range-wide characteristic with Humboldt marten distributions are forest

517 associations with extensive dense shrub cover or complex understory vegetation, which

518 may be indicative of increased food availability or predation escape cover. An

519 understanding of the strength of these interactions and factors that limit populations is

520 needed to make informed conservation decisions. An adaptive management framework

521 with integrated research components may allow for near-term conservation decision

522 making.

523

524 Acknowledgements

525 The desire and decision to request an updated model incorporating newer presence

526 and habitat information was from the Oregon Humboldt Marten stakeholder group,

527 which is facilitated by the U.S. Fish and Wildlife Service in Oregon. Non-invasive marten

528 surveys were conducted by Pacific Northwest and Southwest Research Stations,

529 Oregon State University, Humboldt State University, Green Diamond Resource

530 Company, NCASI, the Siuslaw, Rogue-Siskiyou, and Six Rivers National Forests,

531 Hancock Forest Management, Weyerhaeuser, Oregon Department of Forestry, and the

532 Confederated Tribes of Siletz Indians of Oregon. Detection dog surveys were completed

533 by Rogue Detection Dog Teams and the former group within Conservation Canines, 
534 University of Washington. Considerable aid with field logistics, vehicles, housing, and

535 equipment was provided by the U.S. Fish and Wildlife Service, Salem District BLM,

536 USFS Rogue River-Siskiyou and Siuslaw National Forests, Weyerhaeuser, Hancock

537 Forest Management, and USFS Region 6 Regional Office. We obtained private land

538 access or surveys were completed by trained staff within the ownership for all randomly

539 selected survey points - thanks to Weyerhaeuser, Hancock Forest Management,

540 Starker Forests, and Roseburg Timber for access or data. Reviews by Drs. E. Forsman,

541 D. Miller, and J. Verschuyl, A. Balestrieri, B. Hollen, our anonymous peer reviewer, and

542 the Associate Editor G. Casazza, improved previous versions of this manuscript.

543 Extreme thanks to all field crew leaders (S. Smythe, M. Linnell, B. Peterson, G. W.

544 Watts, J. Bakke, C. Shafer, K. Kooi, and M. Penk) and team members (E. Anderson, D.

545 Baumsteiger, A. Benn, J. Buskirk, B. Carniello, M. Cokeley, S. Hart, P. lacano, A.

546 Kornak, T. McFadden, E. Morrison, A. Palmer, T. Peltier, N. Palazzotto, S. Roon, S.

547 Riutzel, C. Scott, K. Smith, R. Smith, T. Stinson, M. Williams, B. Woodruff, and K.

548 Wright). Any use of trade, firm, or product names is for descriptive purposes only and

549 does not imply endorsement by the U.S. Government.

550 


\section{Literature cited}

552 Balestrieri A, Bogliani G, Boano G, Ruiz-González A, Saino N, Costa S, and Milanesi P. 2016. Modelling the distribution of forest-dependent species in human-dominated landscapes: patterns for the pine marten in intensively cultivated lowlands. PLoS ONE 11:e0158203.

Barry BR. 2018. Distribution, habitat associations, and conservation status of Pacific fisher (Pekania pennanti) in Oregon Thesis. Oregon State University.

Bell DM, Acker SA, Gregory MJ, Davis RJ, and Garcia BA. 2021. Quantifying regional trends in large live tree and snag availability in support of forest management. Forest Ecology and Management 479:118554. https://doi.org/10.1016/j.foreco.2020.118554

562 Bell DM, Gregory MJ, and Davis R. 2020. Gradient nearest neighbor map data quality summary: GNN-2020. In: Service UF, editor: USDA Forest Service and Oregon State University.

Boyce MS, Vernier PR, Nielsen SE, and Schmiegelow FKA. 2002. Evaluating resource selection functions. Ecological Modelling 157:281-300. martes in managed forests of southern boreal Scandinavia. Wildlife Biology 8:289-297.

571 Brown JH, Stevens GC, and Kaufman DM. 1996. The geographic range: size, shape, boundaries, and internal structure. Annual Review of Ecology and Systematics 27:597-623. 
574 Caughley G. 1994. Directions in conservation biology. Journal of Animal Ecology

575

576

577

578

579

580

581

582

583

584

585

586

587

588

589

590

591

592

593

594

595

$63: 215-244$.

CDFW. 2019. Title 14: OAL Matter Number: 2019-0201-02 Endangered Status for Humboldt marten, tri-colored blackbird, fisher southern Sierra ESU. California Department of Fish and Wildlife; 18 Mar 2019 Amendment.

Colwell RK, and Rangel TF. 2009. Hutchinson's duality: The once and future niche. Proceedings of the National Academy of Sciences 106:19651-19658. 10.1073/pnas.0901650106

Crookston N, and Stage A. 1999. Percent canopy cover and stand structure statistics from the forest vegetation simulator. USDA Forest Service, Rocky Mountain Research Station. Gen. Tech. Rep. RMRS-GTR-24.

Daly C, Halbleib M, Smith JI, Gibson WP, Doggett MK, Taylor GH, Curtis J, and Pasteris PP. 2008. Physiographically sensitive mapping of climatological temperature and precipitation across the conterminous United States. International Journal of Climatology: A Journal of the Royal Meteorological Society 28:2031-2064.

Daly C, Helmer EH, and Quiñones M. 2003. Mapping the climate of Puerto Rico, Vieques and Culebra. International Journal of Climatology: A Journal of the Royal Meteorological Society 23:1359-1381.

Darwin C. 1859. The origin of species. 6th edition: John Murray, London.

Davis R, Ohmann J, Kennedy R, Cohen W, Gregory M, Yang Z, Roberts H, Gray A, and Spies T. 2015. Northwest Forest Plan - the first 20 years (1994-2013): status 
and trends of late-successional and old-growth forests USDA Forest Service: Portland, OR, USA.

598 Davis RJ, Hollen B, Hobson J, Gower JE, and Keenum D. 2016. Northwest Forest Plan—the first 20 years (1994-2013): status and trends of northern spotted owl habitats. Portland, OR: U.S. Department of Agriculture, Forest Service, Pacific Northwest Research Station. General Technical Report PNW-GTR-929. p 54. (Martes caurina) in California. Northwest Science. owls to barred owl removal. The Journal of Wildlife Management 80:691-707.

Dugger KM, Forsman ED, Franklin AB, Davis RJ, White GC, Schwarz CJ, Burnham KP, Diller LV, Hamm KA, Early DA, Lamphear DW, Dugger KM, Yackulic CB, Schwarz CJ, Nichols JD, Hines JE, and Yackulic CB. 2016. The effects of habitat, climate, and Barred Owls on long-term demography of Northern Spotted Owls. The Condor

612 Dye AW, Rastogi B, Clemesha RE, Kim JB, Samelson RM, Still CJ, and Williams AP. 2020. Spatial patterns and trends of summertime low cloudiness for the Pacific Northwest, 1996-2017. Geophysical Research Letters 47:e2020GL088121.

615 Elith J, Graham CH, Anderson RP, Dudík M, Ferrier S, Guisan A, Hijmans RJ, Huettmann F, Leathwick JR, Lehmann A, Li J, Lohmann LG, Loiselle BA, Manion G, Moritz C, Nakamura M, Nakazawa Y, Overton JM, Peterson AT, Phillips SJ, 
MS, and Zimmermann NE. 2006. Novel methods improve prediction of species' distributions from occurrence data. Ecography 29:129-151.

621 Elith J, Phillips SJ, Hastie T, Dudík M, Chee YE, and Yates CJ. 2011. A statistical explanation of MaxEnt for ecologists. Diversity and Distributions 17:43-57.

623 Eriksson CE, Moriarty KM, Linnell MA, and Levi T. 2019. Biotic factors influencing the unexpected distribution of a Humboldt marten (Martes caurina humboldtensis) population in a young coastal forest. PLoS ONE 14:e0214653. 10.1371/journal.pone.0214653

627

628

Facka AN, and Moriarty KM. 2017. An approach to foster a new generation of broadscale collaboration within the Martes Working Group. In: Zalewski A, Aubry KB, O'Mahony D, Birks JDS, and Proulx G, eds. The Martes complex in a new millennium: Mammal Research Institute; Polish Academy of Sciences.

Fielding $\mathrm{AH}$, and Bell JF. 1997. A review of methods for the assessment of prediction errors in conservation presence/absence models. Environmental Conservation 24:38-49.

Forchhammer MC, Post E, Berg TB, Høye TT, and Schmidt NM. 2005. Local-scale and short-term herbivore-plant spatial dynamics reflect influences of large-scale climate. Ecology 86:2644-2651.

Franklin JF, and Dyrness CT. 1973. Natural vegetation of Oregon and Washington. USDA Forest Service General Technical Report, Pacific Northwest Forest and Range Experiment Station.

Gamblin HE. 2019. Distribution and habitat use of a recently discovered population of Humboldt martens in California Master of Science. Humboldt State University. 
642 Grinnell J, and Dixon J. 1926. Two new races of the pine marten from the Pacific Coast 643 of North America. University of California Publications in Zoology:411-417.

644 Guisan A, and Thuiller W. 2005. Predicting species distribution: offering more than 645 simple habitat models. Ecology Letters 8:993-1009.

646 Gutiérrez R. 2020. Invited commentary: when a conservation conflict comes full circle 647 the spotted owl conflict is a wicked problem. Journal of Raptor Research 54:337648348.

649 Halvorsen R. 2013. A strict maximum likelihood explanation of MaxEnt, and some 650 implications for distribution modelling. Sommerfeltia 36:1-132.

651 Harrison S, Safford HD, Grace JB, Viers JH, and Davies KF. 2006. Regional and local 652 species richness in an insular environment: serpentine plants in California. $653 \quad$ Ecological Monographs 76:41-56.

654 Hawley VD, and Newby FE. 1957. Marten home ranges and population fluctuations. $655 \quad$ Journal of Mammalogy 38:174-184.

656 Hijmans RJ. 2020. raster: Geographic data analysis and modeling. In: 3.3-13 Rpv, 657 editor. https://CRAN.R-project.org/package=raster.

658 Hirzel AH, Le Lay G, Helfer V, Randin C, and Guisan A. 2006. Evaluating the ability of 659 habitat suitability models to predict species presences. Ecological Modelling 660 199:142-152.

661 Jenness J. 2006. Topographic Position Index (tpi_jen. avx) extension for ArcView 3. x, 662 v. 1.3 a. Jenness Enterprises (accessed May 2019. 
663 Jensen PG, Demers CL, Mcnulty SA, Jakubas WJ, and Humphries MM. 2012. Marten 664 and fisher responses to fluctuations in prey populations and mast crops in the 665 northern hardwood forest. Journal of Wildlife Management 76:489-502.

666 Jones GM, Gutiérrez R, Block WM, Carlson PC, Comfort EJ, Cushman SA, Davis RJ, 667 Eyes SA, Franklin AB, and Ganey JL. 2020. Spotted owls and forest fire:

$668 \quad$ Comment. Ecosphere 11.

669 Kerns BK, and Ohmann JL. 2004. Evaluation and prediction of shrub cover in coastal $670 \quad$ Oregon forests (USA). Ecological Indicators 4:83-98.

671 Kramer-Schadt S, Niedballa J, Pilgrim JD, Schröder B, Lindenborn J, Reinfelder V, 672 Stillfried M, Heckmann I, Scharf AK, Augeri DM, Cheyne SM, Hearn AJ, Ross J, 673 Macdonald DW, Mathai J, Eaton J, Marshall AJ, Semiadi G, Rustam R, Bernard $674 \mathrm{H}$, Alfred R, Samejima H, Duckworth JW, Breitenmoser-Wuersten C, Belant JL, 675 Hofer $\mathrm{H}$, and Wilting A. 2013. The importance of correcting for sampling bias in 676 MaxEnt species distribution models. Diversity and Distributions 19:1366-1379. 10.1111/ddi.12096

678 Kruckeberg AR. 1986. An essay: the stimulus of unusual geologies for plant speciation. 679 Systematic Botany:455-463.

680 Linnell MA, Moriarty K, Green DS, and Levi T. 2018. Density and population viability of 681 coastal marten: a rare and geographically isolated small carnivore. PeerJ

682 6:e4530 - '4521 pg. 10.7717/peerj.4530

683 Loehle C. 2020. Quantifying species' geographic range changes: conceptual and $684 \quad$ statistical issues. Ecosphere 11. 
685 Lombardini M, Cinerari CE, Murru M, Rosin AV, Mazzoleni L, and Meriggi A. 2015.

686 Habitat requirements of Eurasian pine marten Martes martes in a Mediterranean

687 environment. Mammal Research 60:97-105.

688 Manlick PJ, Petersen SM, Moriarty KM, and Pauli JN. 2019. Stable isotopes reveal 689 limited Eltonian niche conservatism across carnivore populations. Functional $690 \quad$ Ecology https://doi.org/10.1111/1365-2435.13266.

691 Manzo E, Bartolommei P, Giuliani A, Gentile G, Dessì-Fulgheri F, and Cozzolino R. 692 2018. Habitat selection of European pine marten in central Italy: from a tree

McGarigal K, Wan HY, Zeller KA, Timm BC, and Cushman SA. 2016. Multi-scale habitat dependent to a generalist species. Mammal Research 63:357-367.

696 selection modeling: a review and outlook. Landscape Ecology:1-15.

697 $10.1007 / \mathrm{s} 10980-016-0374-\mathrm{x}$

McLellan BN. 2015. Some mechanisms underlying variation in vital rates of grizzly bears on a multiple use landscape. The Journal of Wildlife Management 79:749765. https://doi.org/10.1002/jwmg.896

Merow C, Smith MJ, and Silander JA. 2013. A practical guide to MaxEnt for modeling species' distributions: what it does, and why inputs and settings matter. Ecography 36:1058-1069. 10.1111/j.1600-0587.2013.07872.x

Minta SC, Kareiva PM, and Curlee AP. 1999. Carnivore research and conservation:

706 learning from history and theory. In: Clark TW, Curlee AP, Minta SC, and Kareiva PM, eds. Carnivores in ecosystems: the Yellowstone experience. London, United Kingdom: Yale University Press, 323-404. 
707 Moll RJ, Kilshaw K, Montgomery RA, Abade L, Campbell RD, Harrington LA, Millspaugh

708 JJ, Birks JDS, and Macdonald DW. 2016. Clarifying habitat niche width using

709 broad-scale, hierarchical occupancy models: a case study with a recovering

710 mesocarnivore. Journal of Zoology 300:177-185.

$711 \quad$ https://doi.org/10.1111/jzo.12369

712 Morales NS, Fernández IC, and Baca-González V. 2017. MaxEnt's parameter

713 configuration and small samples: are we paying attention to recommendations?

714 A systematic review. PeerJ 5:e3093. 10.7717/peerj.3093

715 Moriarty KM, Linnell MA, Chasco B, Epps CW, and Zielinski WJ. 2017. Using high-

716 resolution short-term location data to describe territoriality in Pacific martens.

717 Journal of Mammalogy 98:679-689.

718 Moriarty KM, Linnell MA, Thornton JE, and Watts III GW. 2018. Seeking efficiency with carnivore survey methods: a case study with elusive martens. Wildlife Society

721 Moriarty KM, Verschuyl J, Kroll AJ, Davis R, Chapman J, and Hollen B. 2019.

722 Describing vegetation characteristics used by two rare forest-dwelling species:

723 Will established reserves provide for coastal marten in Oregon? PLOS ONE

$724 \quad 14:$ e0210865. 10.1371/journal.pone.0210865

725 Nichols JD, Kendall WL, and Boomer GS. 2019. Accumulating evidence in ecology:

726 Once is not enough. Ecology and Evolution 9:13991-14004.

727 Ohmann JL, and Gregory MJ. 2002. Predictive mapping of forest composition and structure with direct gradient analysis and nearest-neighbor imputation in coastal Oregon, USA. Canadian Journal of Forest Research 32:725-741. 
730 Phillips SJ, Anderson RP, and Schapire RE. 2006. Maximum entropy modeling of 731 species geographic distributions. Ecological Modelling 190:231-259.

732 Phillips SJ, and Dudík M. 2008. Modeling of species distributions with Maxent: new 733 extensions and a comprehensive evaluation. Ecography 31:161-175.

734 Prevéy JS, Parker LE, and Harrington CA. 2020. Projected impacts of climate change 735

736 on the range and phenology of three culturally-important shrub species. PLoS ONE 15:e0232537. https://doi.org/10.1371/journal.pone.0232537

737

738

739

740

741

742

743

744

745

746

747

748

749

750

751

752

Prevéy JS, Parker LE, Harrington CA, Lamb CT, and Proctor MF. 2020. Climate change shifts in habitat suitability and phenology of huckleberry (Vaccinium membranaceum). Agricultural and forest meteorology 280:107803.

PSW. 2019. Humbodlt marten data summary and report for the northern coastal California population: distribution and population parameter estimates. USDI Fish and Wildlife Service, USDA Forest Service Pacific Southwest Research Station. p 33.

R Core Team. 2020. R: a language and environment for statistical computing. https://www.R-project.org/. Vienna, Austria: R Foundation for Statistical Computing.

Radosavljevic A, and Anderson RP. 2014. Making better Maxent models of species distributions: complexity, overfitting and evaluation. Journal of Biogeography 41:629-643. https://doi.org/10.1111/jbi.12227

Raphael MG, and Molina R. 2007. Conservation of rare or little-known species: biological, social, and economic considerations. Washington D.C., USA: Island Press. 
753 Rastogi B, Williams AP, Fischer DT, lacobellis SF, McEachern K, Carvalho L, Jones C,

754 Baguskas SA, and Still CJ. 2016. Spatial and temporal patterns of cloud cover

755

756 and fog inundation in coastal California: Ecological implications. Earth Interactions 20:1-19.

757 Safford H, Viers J, and Harrison S. 2005. Serpentine endemism in the California flora: a database of serpentine affinity. Madrono 52:222-257.

759

760

761

762

763

764

765

766

767

768

769

770

771

772

773

(Martes caurina humboldtensis). Arcata, CA.

https://www.fws.gov/arcata/shc/marten/\#report: USDI Fish and Wildlife Service. p 123.

Schwartz MK, Walters AD, Pilgrim KL, Moriarty KM, Slauson KM, Zielinski WJ, Aubry KB, Sacks BN, Zarn KE, and Quinn CB. 2020. Pliocene-early Pleistocene geological events structure Pacific martens (Martes caurina). The Journal of heredity 111:169-181. https://doi.org/10.1093/jhered/esaa005

Searcy CA, and Shaffer HB. 2016. Do ecological niche models accurately identify climatic determinants of species ranges? The American Naturalist 187:423-435.

Shaw JH. 1995. How many bison originally populated western rangelands? Rangelands $17: 148-150$.

Shirk AJ, Raphael MG, and Cushman SA. 2014. Spatiotemporal variation in resource selection: insights from the American marten (Martes americana). Ecological Applications 24:1434-1444. 
774 Siren AP. 2020. Interacting effects of climate and biotic factors on mesocarnivore

775 distribution and snowshoe hare demography along the boreal-temperate

776 ecotoneDissertation. University of Massachusetts, Amherst.

777 Slauson KM, Baldwin JA, and Zielinski WJ. 2012. Occupancy estimation and modeling

778 in Martes research and monitoring. In: Aubry KB, Zielinski W, Raphael MG,

779 Proulx G, and Buskirk SW, eds. Biology and conservation of martens, sables,

780 and fishers: a new synthesis. Ithaca, New York, USA: Comstock Publishing

$781 \quad$ Associates, 343-370.

782 Slauson KM, and Zielinski WJ. 2017. Seasonal specialization in diet of the Humboldt

783 marten (Martes caurina humboldtensis) in California and the importance of prey size. Journal of Mammalogy 98:1697-1708. 10.1093/jmammal/gyx118

785

Slauson KM, Zielinski WJ, and Hayes JP. 2007. Habitat selection by American martens in coastal California. Journal of Wildlife Management 71:458-468.

Slauson KM, Zielinski WJ, LaPlante DW, and Kirk TA. 2019. A landscape suitability model for the Humboldt marten (Martes caurina humboldtensis) in coastal California and coastal Oregon. Northwest Science.

Sofaer HR, Jarnevich CS, Pearse IS, Smyth RL, Auer S, Cook GL, Edwards Jr TC, Guala GF, Howard TG, and Morisette JT. 2019. Development and delivery of species distribution models to inform decision-making. BioScience 69:544-557.

Storch I, Lindstrom E, and de Jounge J. 1990. Diet and habitat selection of the pine 794 marten in relation to competition with the red fox. Acta Theriologica 35:311-320. Buskirk S. 2012. Improved insights into use of habitat by American martens. 
Biology and conservation of martens, sables, and fishers Edited by KB Aubry, WJ Zielinski, MG Raphael, G Proulx, and SW Buskirk Cornell University Press, Ithaca, USA:209-230.

800 Tweedy PJ, Moriarty KM, Bailey JD, and Epps CW. 2019. Using fine scale resolution vegetation data from LiDAR and ground-based sampling to predict Pacific marten resting habitat at multiple spatial scales. Forest Ecology and Management

U.S. Environmental Protection Agency. 2013. Level III ecoregions of the continental 805 United States. EPA- National Health and Environemental Effects Research Laboratory: Corvallis, Oregon, USA.

USFWS. 2019. Species Status Assessment for the coastal marten (Martes caurina), Version 2.1. Arcata, CA, USA: US Fish and Wildlife Service, Region 8. p 141.

USFWS. 2020. Endangered and threatened wildlife and plants; threatened species status for coastal distinct population segment of the Pacific marten with a Section 4(d) rule Federal Register 85:63806-63831.

812 Velleman PF, and Welsch RE. 1981. Efficient computing of regression diagnostics. The American Statistician 35:234-242. 10.2307/2683296

814 Wang T, Hamann A, Spittlehouse D, and Carroll C. 2016. Locally downscaled and spatially customizable climate data for historical and future periods for North America. PLoS ONE 11:e0156720.

817 Warren DL, and Seifert SN. 2011. Ecological niche modeling in Maxent: the importance of model complexity and the performance of model selection criteria. Ecological Applications 21:335-342. 
820 Wasserman TN, Cushman SA, Schwartz MK, and Wallin DO. 2010. Spacial scaling and

821 multi-model Inference in landscape genetics: Martes americana in northern

822 Idaho. Landscape Ecology 25:1610-1612.

823 Whittaker RH. 1960. Vegetation of the Siskiyou mountains, Oregon and California.

$824 \quad$ Ecological Monographs 30:279-338.

825 Wiens JD, Anthony RG, and Forsman ED. 2014. Competitive interactions and resource

826 partitioning between northern spotted owls and barred owls in western Oregon.

$827 \quad$ Wildlife Monographs 185:1-50.

828 Wisz MS, Pottier J, Kissling WD, Pellissier L, Lenoir J, Damgaard CF, Dormann CF,

829 Forchhammer MC, Grytnes JA, and Guisan A. 2013. The role of biotic

830 interactions in shaping distributions and realised assemblages of species:

831 implications for species distribution modelling. Biological Reviews 88:15-30.

832 Zeller KA, Vickers TW, Ernest HB, and Boyce WM. 2017. Multi-level, multi-scale

833 resource selection functions and resistance surfaces for conservation planning:

$834 \quad$ Pumas as a case study. PLoS ONE 12:e0179570.

$835 \quad$ 10.1371/journal.pone.0179570

836 Zielinski WJ, and Golightly R. 1996. The status of marten in redwoods: is the Humboldt

837 marten extinct. Conference on Coast Redwood Forest Ecology and Management

838 (J LeBlanc, ed) Humboldt State University, Arcata, California. Arcata, California, $839 \quad$ USA. $p$ 115-119.

840 Zielinski WJ, Slauson KM, Carroll CR, Kent CJ, and Kudrna DG. 2001. Status of

841 American martens in coastal forests of the Pacific states. Journal of Mammalogy $842 \quad 82: 478-490$. 
843 


\section{Figure 1}

Our study area and modelling region for Humboldt martens (Martes caurina humboldtensis) included all of coastal Oregon and northern California.

We modeled Humboldt marten predicted distributions in forested lands (Panel A, green mask) in 2 ecoregions [left]. We created a minimum convex polygon of known locations buffered by 10-km (hatched area). We compiled 10,229 marten locations, displaying 1,692 marten locations that were not GPS derived and clustered (icon color) from 5,153 surveyed sites with non-detections in light gray, collected during 1996-2020 (panel B). We spatially thinned locations to approximately $500 \mathrm{~m}$ apart, prioritizing den and rest locations and resulting in 384 locations (black dots, panel C). 


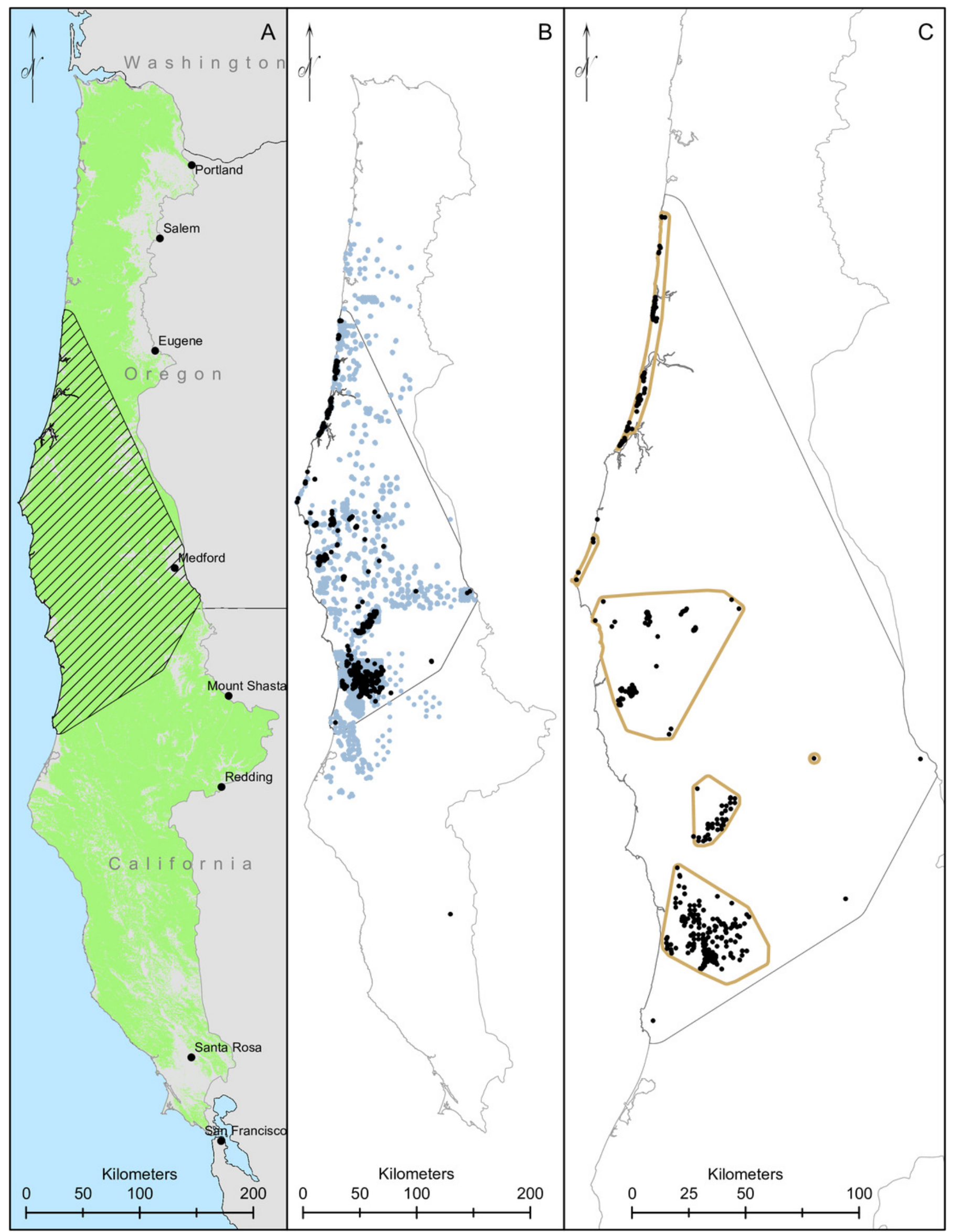




\section{Figure 2}

We investigate the range of variables in our thinned dataset compared to all marten locations and detection/non-detection data.

To provide the range of values observed in this study, we depict boxplots for the variables in the top model showing the thinned marten data (Marten), all non-GPS marten locations (Marten_DB), non-detected but surveyed locations (Non-detection), and random locations within the minimum convex polygon (9,600 random locations). 

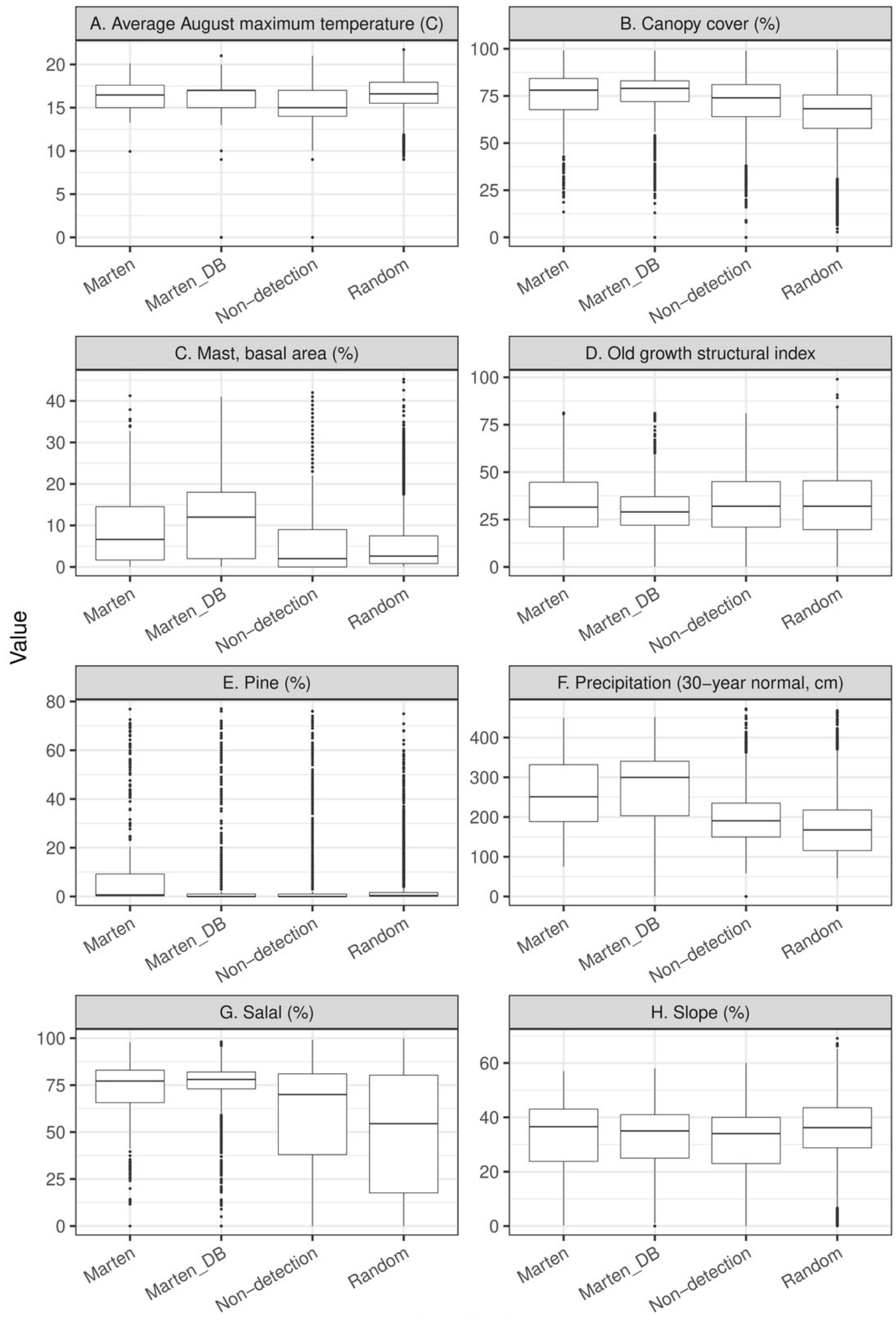

Location type

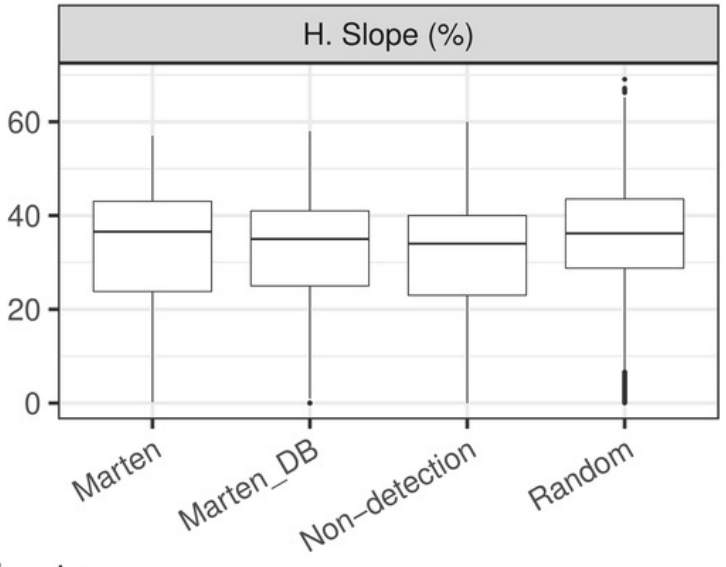




\section{Figure 3}

We depict predicted relationships between Humboldt marten locations and each of the variables within our final model.

Here, each curve is the predicted probability of presence with no conflicting influence of potentially correlated variables. Humboldt marten locations were correlated with both low and high amounts of canopy cover and percent slope (quadratic response). Predicted distribution was positively correlated with predicted salal (Gaultheria shallon) distribution, percentage of pine, precipitation, and mast. We observed a negative correlation between marten locations and August temperature. We observed a slight negative relationship between marten locations and the old growth structural index. Our figure order matches the percent contribution values reported in Table 2. The curves reveal the mean response (black) and standard deviation (gray) for 10 replicate Maxent runs. 

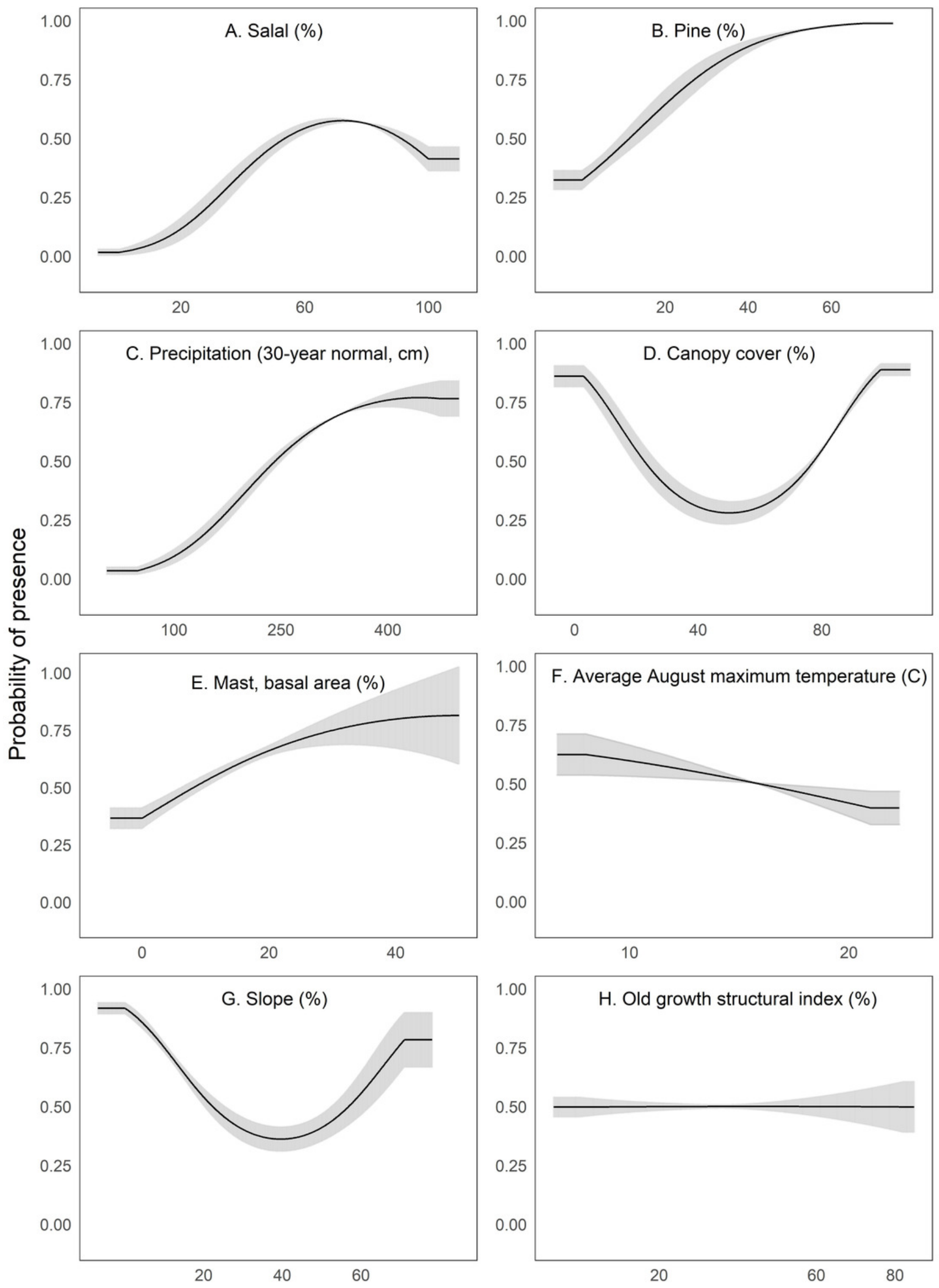


\section{Figure 4}

Our predicted suitable transitions for Humboldt marten (Martes caurina humboldtensis) range.

We present mean predicted vs. expected curve (solid black line) from our model replicates, showing 95-percent confidence intervals (gray-shaded vertical bars). The P/E $=1$ threshold is where the curve crosses the random chance line (horizontal orange line), and the blue dashed vertical lines are the 95-percent confidence intervals. We used the predicted-toexpected curve to inform our suitability thresholds following Hirzel et al. (2006), including predicted unsuitable ( $P / E$ and confidence intervals $0-1$ ), marginal ( $P / E>1$ but overlapping confidence intervals), and suitable (P/E and confidence intervals $>1$; map depicted in Fig. 5).

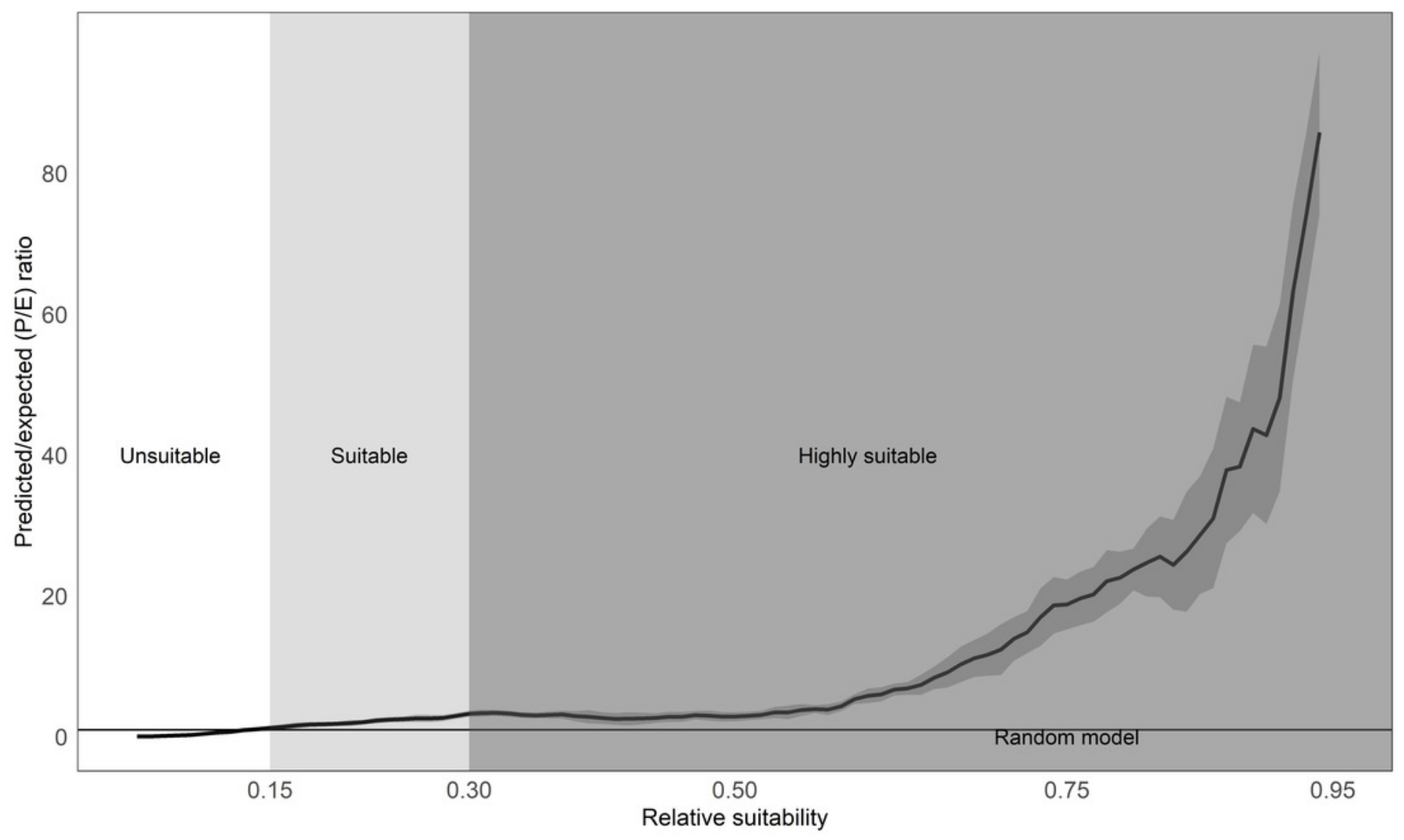




\section{Figure 5}

We display our modeled predicted range for Humboldt marten (Martes caurina humboldtensis).

For predicted range, we followed Hirzel et al. (2006) with predicted versus expected ratios transitioning between predicted highly suitable (green), suitable (orange), and marginal or not predicted suitable (gray). Marten location information was displayed (black dots). We zoomed to population extents to provide increased visual resolution within the Central Oregon Coast (Panel 3a), South coast (Panel 3b), and northern California (Panel 3c). 


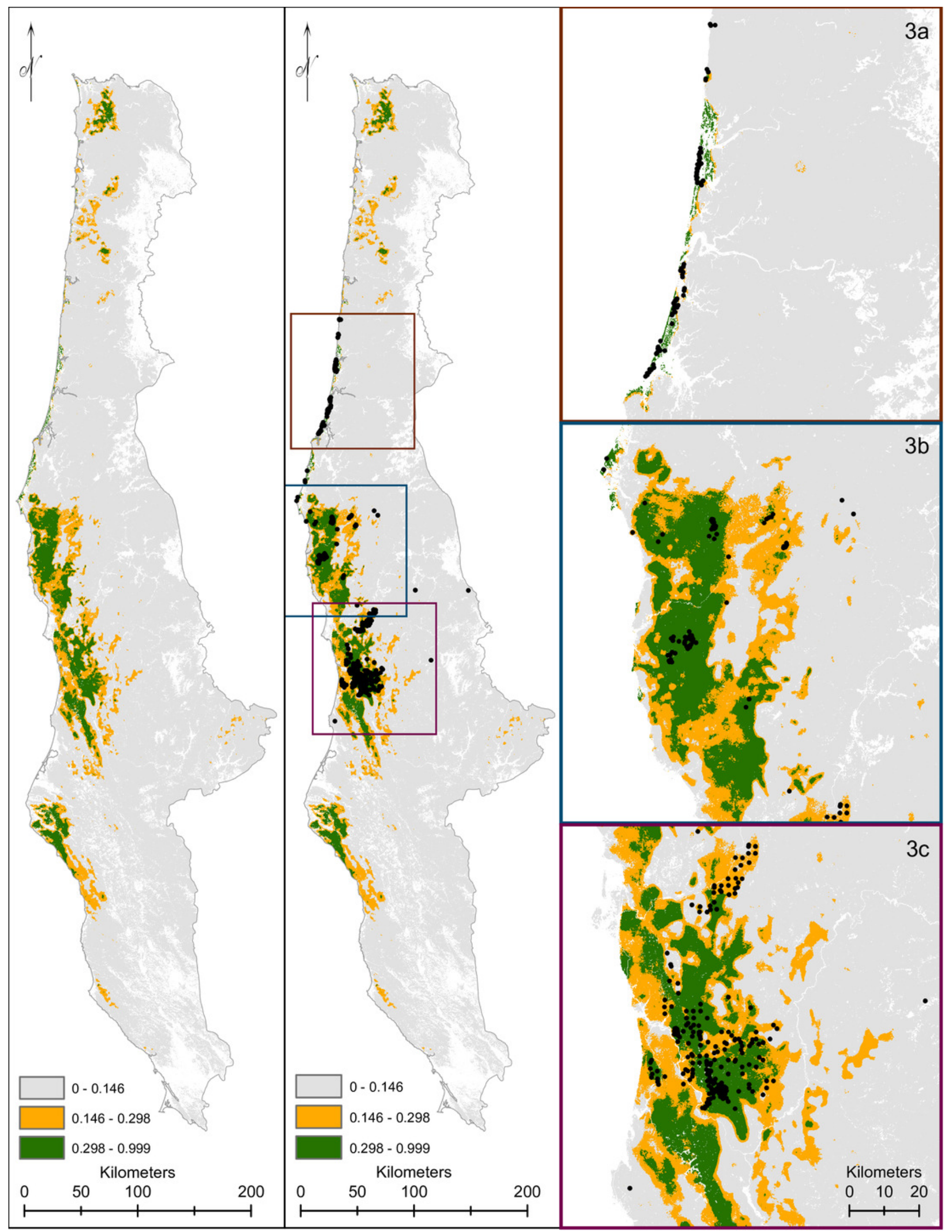




\section{Table $\mathbf{1}$ (on next page)}

Data ranges, means, and standard deviations for the model region, the contemporary Humboldt marten distribution, and at Humboldt marten locations.

We depict individual layer statistics within our Humboldt marten (Martes caurina humboldtensis) model region in coastal Oregon and northern California. We display the variable, optimized spatial scale with a radius in meters, value range from the coastal ecoregions, means and standard deviation (SD) for the model region, minimum convex polygon around all known marten locations (MCP), and values from spatially thinned marten locations $(n=384)$, our layer source, and a description of that variable. We only considered variables with $<60 \%$ correlation in our final model (Table S2). 
Table 1:

Data ranges, means, and standard deviations for the model region, the contemporary Humboldt marten distribution, and at Humboldt marten locations.

We depict individual layer statistics within our Humboldt marten (Martes caurina humboldtensis) model region in coastal Oregon and northern California. We display the variable, optimized spatial scale with a radius in meters, value range from the coastal ecoregions, means and standard deviation (SD) for the model region, minimum convex polygon around all known marten locations (MCP), and values from spatially thinned marten locations $(n=384)$, our layer source, and a description of that variable. We only considered variables with $<60 \%$ correlation in our final model (Table S2).

\begin{tabular}{|c|c|c|c|c|c|c|c|}
\hline Variable & Scale & $\begin{array}{l}\text { Value } \\
\text { Range }\end{array}$ & $\begin{array}{l}\text { Model } \\
\text { Region } \\
\text { (Mean } \pm \\
\text { SD) }\end{array}$ & $\begin{array}{c}\text { Minimum } \\
\text { convex } \\
\text { polygon } \\
\text { (Mean } \pm \\
\text { SD) } \\
\end{array}$ & $\begin{array}{l}\text { Marten } \\
\text { Locations } \\
\text { (Mean } \pm \\
\text { SD) }\end{array}$ & Source & Description \\
\hline $\begin{array}{l}\text { Forest age, } \\
\text { years }\end{array}$ & 270 & $0-712$ & $95.5 \pm 43$ & $104.3 \pm 49.4$ & $109.8 \pm 69.6$ & $\begin{array}{l}2016 \\
\text { GNN }\end{array}$ & $\begin{array}{l}\text { Basal area weighted stand age } \\
\text { based on field recorded or modeled } \\
\text { ages of dominant/codominant trees }\end{array}$ \\
\hline $\begin{array}{l}\text { Canopy cover } \\
(\%)\end{array}$ & 1170 & $2-99$ & $65.9 \pm 13$ & $66.4 \pm 14$ & $71.3 \pm 18.6$ & $\begin{array}{l}2016 \\
\text { GNN }\end{array}$ & $\begin{array}{l}\text { Canopy cover percentage of all live } \\
\text { trees }\end{array}$ \\
\hline $\begin{array}{l}\text { Coastal } \\
\text { proximity }\end{array}$ & 50 & $2-700$ & $\begin{array}{c}511.7 \pm \\
193.1\end{array}$ & $\begin{array}{c}516.3 \pm \\
203.1\end{array}$ & $\begin{array}{c}361.8 \pm \\
197.9\end{array}$ & PRISM & $\begin{array}{l}\text { Optimal path length from the } \\
\text { coastline accounting for terrain } \\
\text { blockage (Daly et al. 2008) }\end{array}$ \\
\hline $\begin{array}{l}\text { Diameter } \\
\text { diversity index }\end{array}$ & 1170 & $26-811$ & $433.9 \pm 103$ & $\begin{array}{c}437.6 \pm \\
111.7\end{array}$ & $\begin{array}{c}459.4 \pm \\
123.6\end{array}$ & $\begin{array}{l}2016 \\
\text { GNN }\end{array}$ & $\begin{array}{l}\text { Diameter diversity index - measure } \\
\text { of stand structure based on tree } \\
\text { densities in diff. } \mathrm{DBH} \text { classes }(x 100)\end{array}$ \\
\hline $\begin{array}{l}\text { Percent downed } \\
\text { wood }\end{array}$ & 270 & $0-797$ & $69.3 \pm 54.7$ & $70.9 \pm 50$ & $68.5 \pm 60.1$ & $\begin{array}{c}2016 \\
\text { GNN } \\
\text { (created) }\end{array}$ & $\begin{array}{l}\text { Created within GNN to estimated } \\
\text { percentage of large downed wood, a } \\
\text { component of OGSI }\end{array}$ \\
\hline Salal & 1170 & $0-100$ & $35.7 \pm 30.9$ & $50.7 \pm 32.3$ & $72.7 \pm 17.8$ & Prevéy & $\begin{array}{l}\text { Probability of Gautheria shallon } \\
\text { species occurrence (Prevéy et al. } \\
2020 \text { ) }\end{array}$ \\
\hline
\end{tabular}




\begin{tabular}{|c|c|c|c|c|c|c|c|}
\hline $\begin{array}{l}\text { Masting } \\
\text { vegetation }\end{array}$ & 1170 & $0-72$ & $5.9 \pm 7.4$ & $5.2 \pm 6.7$ & $9.3 \pm 9$ & $\begin{array}{l}2016 \\
\text { GNN }\end{array}$ & $\begin{array}{l}\text { Percent of stand basal comprised of } \\
\text { tanoak (Notholithocarpus } \\
\text { densiflorus; LIDE), giant chinquapin } \\
\text { (Castanopsis chrysophylla; CHCH), } \\
\text { coastal live oak (Quercus agrifolia; } \\
\text { QUAG), canyon live oak (Quercus } \\
\text { chrysolepis; QUCH), and California } \\
\text { bay (Umbellularia californica; UMCA) } \\
\text { (mast producing evergreen } \\
\text { hardwoods, indicator of prey } \\
\text { abundance) }\end{array}$ \\
\hline $\begin{array}{l}\text { Old growth } \\
\text { structural index }\end{array}$ & 50 & $0-100$ & $32.7 \pm 15.8$ & $33.2 \pm 16.1$ & $33.8 \pm 16.9$ & $\begin{array}{l}2016 \\
\text { GNN }\end{array}$ & $\begin{array}{l}\text { Old-growth structure index based on } \\
\text { abundance of large live trees, snags, } \\
\text { down wood, and ddi }\end{array}$ \\
\hline Percent pine & 1170 & $0-94$ & $1.2 \pm 3.5$ & $1.5 \pm 4.5$ & $10.9 \pm 20.1$ & $\begin{array}{l}2016 \\
\text { GNN }\end{array}$ & $\begin{array}{l}\text { Percent of pixel basal area } \\
\text { comprised of shore pine (Pinus } \\
\text { contorta; PICO), Jefferey pine (Pinus } \\
\text { jeffreyi; PIJE) and knobcone pine } \\
\text { (Pinus attenuata; PIAT). We use this } \\
\text { as an indicator of serpentine and } \\
\text { coastal dune environments. }\end{array}$ \\
\hline Percent slope & 1170 & $0-74$ & $33.8 \pm 10.9$ & $36.2 \pm 10.6$ & $31.7 \pm 15.8$ & $\begin{array}{l}\text { USGS } \\
\text { DEM }\end{array}$ & Percent slope in degrees \\
\hline Precipitation & 1170 & $13-198$ & $66.9 \pm 27$ & $70 \pm 30.1$ & $102.4 \pm 30.5$ & $\begin{array}{l}2016 \\
\text { GNN }\end{array}$ & $\begin{array}{l}\text { Average annual precipitation 1981- } \\
2010 \text { (inches) }\end{array}$ \\
\hline $\begin{array}{l}\text { Large snag } \\
\text { density }\end{array}$ & 742 & $0-48$ & $4.9 \pm 4.3$ & $5.8 \pm 4.6$ & $6.9 \pm 4.9$ & $\begin{array}{c}2016 \\
\text { GNN } \\
\text { (created) } \\
\end{array}$ & $\begin{array}{l}\text { Created within GNN to estimated } \\
\text { density of large snags, a component } \\
\text { of OGSI }\end{array}$ \\
\hline $\begin{array}{l}\text { Temperature } \\
\text { (August max) }\end{array}$ & 1170 & $8-24$ & $16.5 \pm 2.3$ & $16.1 \pm 1.7$ & $16.4 \pm 1.7$ & PRISM & $\begin{array}{l}\text { Average annual maximum } \\
\text { temperature } 1981-2010 \text { (Celcius). }\end{array}$ \\
\hline $\begin{array}{l}\text { Topographic } \\
\text { position index }\end{array}$ & 270 & $\begin{array}{c}-149- \\
174\end{array}$ & $0.7 \pm 26.7$ & $1.1 \pm 28.8$ & $-0.3 \pm 28.6$ & $\begin{array}{l}\text { USGS } \\
\text { DEM }\end{array}$ & $\begin{array}{l}\text { Topographic position index - } \\
\text { difference of cell elevation with } \\
\text { mean of all cells w/in } 450 \mathrm{~m} \text { radius }\end{array}$ \\
\hline
\end{tabular}




\begin{tabular}{|l|c|c|c|c|c|c|l|}
\hline $\begin{array}{l}\text { Large tree } \\
\text { density }\end{array}$ & 1170 & $0-47$ & $3.2 \pm 3.5$ & $4.4 \pm 4.2$ & $5.2 \pm 5.9$ & $\begin{array}{c}2016 \\
\text { GNN } \\
\text { (created) }\end{array}$ & $\begin{array}{l}\text { Created within GNN to estimated } \\
\text { density of large trees, a component } \\
\text { of OGS }\end{array}$ \\
\hline Huckleberry & 1170 & $2-99$ & $32.7 \pm 24.6$ & $39.1 \pm 26$ & $42.7 \pm 27.2$ & Prevéy & $\begin{array}{l}\text { Probability of species occurrence for } \\
\text { Vaccinium ovatum (created) }\end{array}$ \\
\hline
\end{tabular}




\section{Table 2 (on next page)}

We show the percent contribution and permutation importance from our top Maxent model.

We ordered variables by their percent contribution and report the optimized spatial scale (focal radius in meters), the univariate response type, and whether the univariate dependent plots were generally positively or negatively correlated with Humboldt marten (Martes caurina humboldtensis) locations. 
Table 2:

2 We show the percent contribution and permutation importance from our top Maxent model.

3 We ordered variables by their percent contribution and report the optimized spatial scale (focal radius in meters), the univariate 4 response type, and whether the univariate dependent plots were generally positively or negatively correlated with Humboldt marten 5 (Martes caurina humboldtensis) locations.

\begin{tabular}{|l|c|c|c|c|c|}
\hline & Scale & Response & $\begin{array}{c}\text { Univariate } \\
\text { Relationship }\end{array}$ & $\begin{array}{c}\text { Percent } \\
\text { contribution }\end{array}$ & $\begin{array}{c}\text { Permutation } \\
\text { importance }\end{array}$ \\
\hline Salal & 1170 & Quadratic & + & 23.3 & 15.5 \\
\hline Percent pine & 1170 & Product & + & 22.5 & 30.3 \\
\hline Precipitation_30-year average & 1170 & Product & + & 21.6 & 25.3 \\
\hline Canopy cover & 1170 & Quadratic & + & 18.7 & 20.2 \\
\hline Mast & 1170 & Product & + & 5.4 & 1.3 \\
\hline $\begin{array}{l}\text { August temperature_30-year } \\
\text { average }\end{array}$ & 1170 & Linear & - & 4.7 & 2.3 \\
\hline Percent slope & 1170 & Quadratic & - & 2.7 & 4.4 \\
\hline Old growth structural index & 50 & Linear & - & 1.2 & 0.7 \\
\hline
\end{tabular}

